\title{
CHINA'S UNLAWFUL CONTROL OVER TIBET: THE TIBETAN PEOPLE'S ENTITLEMENT TO SELF-DETERMINATION
}

\section{INTRODUCTION}

Few people who travel to the Himalayas realize that hundreds of Tibetans have traveled over the area to flee Chinese-occupied Tibet. ${ }^{\prime}$ As one twenty-one year old male from Chamdo remembered:

It was very difficult crossing over the mountains. The snow was up to our waists, but I was so anxious to reach Nepal I kept walking, I didn't give up. We heard that refugees often die in the mountains because of the cold. We joined a guide with five children; one small boy almost died, we took turns carrying him. For three days I was snow blind and couldn't see anything.

We know our Tibetan mountains, we know how to hide in them, but Nepal is unfamiliar to us; it is easy for the Nepalese to catch and arrest us. I didn't want to leave my country, but living in Tibet has become difficult. In India we will be protected by His Holiness the Dalai Lama. Only then, will we be able to work for our country's independence. ${ }^{2}$

This Note will demonstrate that the Tibetan people are entitled to exercise their right to self-determination because the Chinese are attempting to destroy the Tibetan way of life by illegally controlling Tibet. ${ }^{3}$ This Note will also demonstrate that the Chinese do not have a valid claim to rule Tibet because the Seventeen Point Agreement, which the Chinese rely on, is void under international law. ${ }^{4}$

The Chinese assert that Tibet has been a part of China since the Thirteenth century. ${ }^{5}$ This is contrary to Tibet's claim that the Tibetan people were independent prior to China's invasion. ${ }^{6}$ Part II of this Note will discuss

1. See The Situation of Tibet and its People: Hearing on S. Hrg. 105-124 Before the Senate Committee on Foreign Relations, 105th Cong. 76 (1997) (An Issue of Protection: Tibetan Refugees by Maura Moynihan) [hereinafter Senate Hearing]. generally id.

2. Id. at 82. For accounts by other Tibetans leaving Tibet to resettle in India, see

3. See INTERNATIONALCOMMISSION OFJURISTS, THEQUESTION OF TIBET AND THE RULE OF LAW 21 (1959) [hereinafter ICJ].

4. See infra notes 90-99 and accompanying text.

5. See Frederick J. Petersen, The Façade of Humanitarian Intervention for Human Rights in a Community of Sovereign Nations, 15 ARIZ. J. INT'L \& COMP. L. 871, 899 (1998).

6. See id. 
the history of Tibet and how the government of Tibet has evolved over the centuries. ${ }^{7}$

The Seventeen Point Agreement, which allegedly gives China the power to rule Tibet, was signed under coercion. ${ }^{8}$ Part III of this Note will discuss the legality of the Seventeen Point Agreement, ${ }^{9}$ and China's violations of the Agreement. ${ }^{10}$ Part IV will discuss the human rights instruments of which China is a member." "As a result of the Chinese occupation, Tibetans in Tibet are deprived of their basic human rights." 12 Part V will discuss human rights violations that China imposes upon the Tibetans. ${ }^{13}$

Part VI of this Note will discuss the right to self-determination with a major portion discussing the benefits of pursuing Tibet's right to selfdetermination. ${ }^{14}$ "The right to self-determination expressly incorporates cultural integrity by guaranteeing the right of peoples to pursue economic, social, and cultural development."15 The basis of democracy, the notion that the government should earn its authority from the people, is also the basis for self-determination. ${ }^{16}$

\section{HISTORY OF TIBET ${ }^{17}$ AND ITS GOVERNMENT}

\section{A. History of Tibet Pre- and Post-Chinese Occupation}

The Chinese Emperor and the Tibetan Emperor signed the Tibet-China Treaty in 821 A.D. ${ }^{18}$ This Treaty, designed as a peace treaty, ${ }^{19}$ was documented in Tibetan and Chinese on three pillars located at Tibet's capital,

7. See infra notes 18-89 and accompanying text.

8. See Michael C. Van Walt van PraAg, The Status of Tibet: History, Rights, AND PROSPECTS IN INTERNATIONAL LAW 154 (1987).

9. See infra notes $91-99$ and accompanying text.

10. See infra notes $100-113$ and accompanying text.

11. See infra notes 114-179 and accompanying text.

12. Guidelines for Future Tibet's Polity and the Basic Features of its Constitution at http://www.tibet.com/future.html (last visited Oct. 2, 2001). See also infra notes 180-288 and accompanying text.

13. See infra notes $180-288$ and accompanying text.

14. See infra notes 289-338 and accompanying text.

15. Michele L. Radin, The Right to Development as a Mechanism for Group Autonomy: Protection of Tibetan Cultural Rights, 68 WASH. L. REV. 695, 705 (1993).

16. See VAN WALT VAN PRAAG, supra note 8 , at 190.

17. For a summary of the history of Tibet see generally HUGH E. RICHARDSON, TIBET AND ITS HISTORY (2nd ed. 1984).

18. See VAN WALT VAN PRAAG, supra note 8 at 1 . With this treaty, the Chinese and Tibetans confirmed boundaries and promised to respect each other's sovereignty. See also Tibet: Two Distinct Views at http://www.rangzen.com/history/views.htm (last visited Sept. 6, 2001) [hereinafter Rangzen].

19. See VAN WALT VAN PRAAG, supra note 8, at 1 . This treaty was "meant to end almost two centuries of fighting." Id. 
China's capital, and a city located at the border ${ }^{20}$ This Treaty allowed China to control the whole region to the East while giving Tibet control of the region to the West. ${ }^{21}$

Between 907 and 1276 A.D., the Tibetan government had little if any contact with the Chinese government. ${ }^{22}$ It was not until the Mongols captured China and Tibet that contacts between the two countries were restored. ${ }^{23}$ Therefore, the Chinese claim a right to Tibet based on the past influence the Mongols $^{24}$ and Manchus ${ }^{25}$ exerted over Tibet. ${ }^{26}$

The Mongols ruled over Tibet from $1259^{27}$ until 1350 and over China from 1279 until 1368 and established the Yuan Dynasty in later years. ${ }^{28}$ During the 13th century when the Mongols expanded to China in the East, the Tibetan leaders concluded an agreement with the Mongols to avoid the inevitable capture of Tibet. ${ }^{29}$ This agreement "promised political allegiance and religious blessings and teachings in exchange for patronage and protection."30 A Tibetan Lama, Sakya Pandita, was summoned to Prince Goden' $\mathrm{s}^{31}$ Court, in which the Lama introduced Buddhism and Tibet's culture to the Mongols. ${ }^{32}$ Because of Sakya Pandita's loyalty, he was given temporal authority over all of Tibet. ${ }^{33}$ There is no evidence that the Mongols integrated Tibet and China, ${ }^{34}$ and throughout the Mongolian domination, "Tibet remained a unique part of the Empire and was never fully integrated into [the Mongolian Empire]."35

20. See id. This treaty is "most significant because it reveals, in clear and unambiguous language, the nature of Sino-Tibetan relations at the time." Id.

21. See id.

22. See id. at 4.

23. See id. at 4-5.

24. See id. at 5-7. The Mongols, under Chingis Khan's rule, came from Central Asia and began a series of conquests, including Tibet and China, which led to the establishment of the Yuan Dynasty, one of the greatest empires in the world. See id.

25. See id. at 11. The Manchus, who invaded and conquered China, established the Qing Dynasty. See id.

26. See Tibet File No. 11: The Legal Status of Tibet at http://www.freetibet.org/ info/file18.htm (last visited Sept. 23, 2001) [hereinafter File No. 11].

27. See VAN WALT VAN PRAAG, supra note 8, at 6 . This was the year in which Kubilai Khagan established a definite degree of authority over Tibet. See id. However, there are some records that state the Tibetans gave in to Chingis Khan as early as 1207 . See id. at 5.

28. See id. at 5-6.

29. See File No. 11, supra note 26.

30. Id.

31. See VAN Walt VAN PRAaG, supra note 8, at 5 . Prince Goden was the grandson of Chingis Kahn and ruler of Kokonor. See id.

32. See id.

33. See id.

34. See File No. 11, supra note 26.

35. VAN WALT VAN PRAAG, supra note 8, at 6. "[L]icensed border markets continued to exist for trade between China and Tibet, as they existed nowhere in Yuan China." Id. 
The Tibetans broke away from the Yuan Dynasty prior to China, ${ }^{36}$ under the lay myriarch Changchub Gyaltsen ${ }^{37}$ and became once again a sovereign nation. ${ }^{38}$ Once China broke away from the Yuan Dynasty, the Chinese established the Ming Dynasty and did not show any interest in taking over Tibet. ${ }^{39}$ The rise of the fifth incarnation, ${ }^{40}$ known as the Great Fifth, gave the Dalai Lama the power to rule over Tibet. ${ }^{41}$

In 1644, the Manchus invaded and conquered China and established the Qing Dynasty. ${ }^{42}$ The Manchus developed close ties with the Tibetans and the Dalai Lama, who then agreed to be the spiritual guide of the Manchu emperor. ${ }^{43}$ Some Manchu rulers exerted some degree of influence over Tibet, such as sending troops into Tibet to protect the Tibetans from foreign invasion or internal turmoil. ${ }^{44}$ However, this influence over Tibet was not a type of weakness that entailed the legal extinction of a State. ${ }^{45}$ The Manchu rule was ineffective by 1904 and ceased to exist by $1911 .^{46}$

Following the Manchus invasion in 1644, the British government wanted to reestablish Indian trade with Tibet in 1873 , but was not sure whether to negotiate with the Chinese Government or the Tibetan Government in Lhasa, because at that time, the "legal position of Tibet was ambiguous."

Tibet had re-emerged as a fully sovereign state in $1912 .^{48}$ On December 12 , 1912, the Mongolian and Tibetan Governments concluded the Treaty of Friendship and Alliance, ${ }^{49}$ in which Tibet and Mongolia declared themselves

36. See id. at 6-7. China regained its independence in 1368 , while the Tibetans regained their independence in 1350. See id.

37. See id. at 6. Changchub Gyaltsen established himself as the ruler of the newly unified and centralized Tibet. See id.

38. See id. at 7. See also, File No. 11, supra note 26.

39. See VAN WALT VAN PRAAG, supra note 8 , at 7 .

40. See id. at 8 . This idea of incarnation is "based on the belief that human beings who have attained a very high degree of enlightenment can reincarnate voluntarily and out of compassion, in order to help all living beings on their path to final liberation." Id.

41. See id. at 10.

42. See id. at 11.

43. See File No. 11, supra note 26 . This relationship was the only "formal" tie and it had no effect on Tibet's status as a sovereign state. See id.

44. See id.

45. See id.

46. See id. See also VAN WaLt VAN PRAAG, supra note 8, at 11 . The Chinese overthrew the Qing Dynasty in 1911 to set up China's own native rule. See id.

47. ICJ, supra note 3 , at 75 .

48. See id. at 85 . It has been viewed that the overthrow of the Manchu dynasty severed the link between China and Tibet, and the Tibetans believed they were independent from China in fact and in law. See id.

49. The preamble states: Mongolia and Thibet [sic], having freed themselves from the dynasty of the Manchus and separated from China, have formed their own independent States, and, having in view that both States from time immemorial have professed one and the same religion, with a view to strengthening their historic and mutual friendship . . . have made the following agreement.

Treaty of Friendship and Alliance, ICLT - Legal Materials on Tibet - Treaties and Conventions Relating to Tibet at http://www.tibeticlt.org/materials/treaties/treaties $14 . \mathrm{html}$ (last 
as independent states free from Manchu rule. ${ }^{50}$ The Tibetans' position was one of de facto independence. ${ }^{51}$

China invaded Tibet in 1949, at which time Tibet possessed internationally recognized attributes of independence, such as a government, a defined territory, and the ability to carry out international relations. ${ }^{52}$ At the time of the invasion, China believed that it was liberating Tibet from foreign imperialists. ${ }^{53}$ China then "incorporated Tibet as the Tibetan Autonomous Region." 54

\section{B. Chinese Government in Tibet}

China invaded the de facto independent province in 1950 and forced an agreement on the Tibetans in 1951 that established Chinese rule. ${ }^{55}$ With most of the eastern region of Tibet occupied and the Tibetan army in disarray, the Tibetans' only alternative was to negotiate with China. ${ }^{56}$ As negotiations continued, the Tibetans' positions ${ }^{57}$ were rejected, and the delegation was threatened and virtually held hostage by the Chinese. ${ }^{58}$ The Agreement of the Central People's Government and the Local Government of Tibet on Measures for the Peaceful Liberation of Tibet, known as the Seventeen Point Agreement, ${ }^{59}$ was concluded and signed on May 23, $1951 .^{60}$ The Agreement does not contain the official seal of Tibet because the delegation, not having

visited Oct. 2, 2001). See also VAN WALT VAN PRAAG, supra note 8, at 320.

50. See VAN WALT VAN PRAAG, supra note 8 , at 50.

51. See ICJ, supra note 3, at 85. "[T]here are ... also strong legal grounds for thinking that any form of legal subservience to China has vanished." Id.

52. See Rangzen, supra note 18.

53. See Radin, supra note 15 , at 698 . China insists that "Tibet never existed as an independent state, and even if it had, Tibetans exercised their self-determination and chose integration with China." Id. at 698-699.

54. Id. at 699.

55. See Michael J. Kelly, Political Downsizing: The Re-Emergence of Self-Determination, and the Movement Toward Smaller, Ethnically Homogenous States, 47 DRAKE L. REV. 209, 270 (1999).

56. See The Seventeen Point Agreement at http://www.tibet.ca/pub/17Point Agreement.htm (last visited Sept. 21, 2001) [hereinafter Tibet.ca].

57. One particular demand was that Chinese armies not be stationed in Tibet. See id. See also VAN WALT VAN PRAAG, supra note 8, at 82 . Another demand was the return of territories under Chinese control. See id. Finally, the Tibetans demanded that the Chinese respect the boundaries of Tibet. See id.

58. See Tibet.ca, supra note 56. The delegation was not allowed to contact the Cabinet or the Dalai Lama but instead had to comply with China's position. See id.

59. Article 1 provides: "The Tibetan people shall be united and drive out imperialist aggressive forces from Tibet; the Tibetan people shall return to the big family of the motherland the People's Republic of China." The Agreement of the Central People's Government and the Local Government of Tibet on Measures for the Peaceful Liberation of Tibet, available at http://www.tibetjustice.org/materials/China/china3.html (last visited March 10, 2002) [hereinafter Seventeen Point Agreement]. See also ICJ, supra note 3, at 140. See also Part III infra and notes 90 to 113 and accompanying text.

60. See Tibet.ca, supra note 56. 
final authority to sign, did not have possession of the Tibetan seal. ${ }^{61}$ The preamble $^{62}$ to the Agreement allows for the exercise of regional autonomy where a profuse amount of national minorities are located. ${ }^{63}$

China issued a document known as the China White Paper, which provides the Chinese government's position on Tibet. ${ }^{64}$

China's invasion and occupation of Tibet is termed a liberation from traditional Tibetan society. ${ }^{65}$ However, this justification for liberation is unacceptable. ${ }^{66}$ First, international law does not allow one country to "invade, occupy, annex and colonize another country just because its social structure does not please it." ${ }^{167}$ Second, China brought about more suffering in the name of liberation. ${ }^{68}$ Finally, Tibetans are capable of reforming the standard of human rights within their society. ${ }^{69}$

The celebration of the fiftieth anniversary of the signing of the Seventeen Point Agreement in May 2001 indicates the continued reliance by the Chinese on this document as a means of giving legitimacy to their claim over the Tibetan region. ${ }^{70}$

61. See id. The seal appearing on the agreement was allegedly forged by the Chinese authorities. See id.

62. A portion of the preamble states:

[T]he Central People's Government declared that all nationalities within the boundaries of the People's Republic of China are equal, and that they shall establish unity and mutual aid and oppose imperialism and their own public enemies, so that the People's Republic of China may become one big family of fraternity and cooperation. . . [and] national regional autonomy is to be exercised in areas where national minorities are concentrated, and all national minorities are to have freedom to develop their spoken and written languages and to preserve or reform their customs, habits, and religious beliefs, and the Central People's Government will assist all national minorities to develop their political, economic, cultural, and educational construction work. ... [I]n order that the Tibetan nationality and people may be freed and return to the big family of the People's Republic of China to enjoy the same rights of national equality as all other nationalities in the country and develop their political, economic, cultural, and educational work.... The result of the talks is that both parties have agreed to establish this agreement and ensure that it be carried into effect.

Seventeen Point Agreement, supra note 59. See also VAN WALT VAN PRAAG, supra note 8, at 337-38.

63. See Tibet.ca, supra note 56.

64. See Tibet File No. 16: China White Paper at http://www.freetibet.org/info/file16.htm (last visited Sept. 23, 2001).

65. See Central Tibetan administration, Tibet: Proving Truth from Facts 40 (1996) [hereinafter PROVING].

66. See id.

67. Id.

68. See id.

69. See id.

70. See Tibet Information Network - Anniversary of 17-Point Agreement in Tibet, May 3, 2001, at http://www.tibetinfo.net/news-updates/nu030501.htm (last visited Sept. 23, 2001) [hereinafter Tibetinfo.net]. People were "notified that participation in the celebrations is "an important political responsibility."' Id. 


\section{Tibetan Government-in-Exile}

The Tibetan Government-in-Exile, ${ }^{72}$ also known as the Central Tibetan Administration (CTA), ${ }^{73}$ is located in Dharamsala, India, which is currently home to the Dalai Lama. ${ }^{74}$ If an exiled government is recognized as an authority, then it is accorded treatment due to its status as a government. ${ }^{75}$ The term government-in-exile indicates the location of the government. ${ }^{76}$ The recognition of governments-in-exile combines the subjective concept of recognition ${ }^{77}$ and the objective concept of government. ${ }^{78}$

The Tibetans created this government to represent the Tibetan people after the Chinese occupation. ${ }^{79}$ The CTA organizes the struggle for the selfdetermination of the Tibetan people. ${ }^{80}$ The three organs of the CTA, as created by the Tibetan Constitution, are: the judiciary; the legislature, known as the Assembly of Tibetan People's Deputies; and the executive, known as the Kashag. ${ }^{81}$ The judiciary is responsible for adjudicating all civil disputes within the exiled community, unless it would be contrary to the host country's laws. ${ }^{82}$ The Legislature is responsible for passing new laws and for amending or repealing old laws. ${ }^{83}$ The Kashag is elected by and answers to the legislature. ${ }^{84}$

71. For a general discussion on governments-in-exile see generally STEFAN TALMON, RECOGNITION OF Governments In InTERnational LAW (Clarendon Press, 1998).

72. See TALMON, supra note 71 , at 7 . There are situations in which it may be necessary for States to announce their decision to recognize an authority as the government of a particular State. See id. The Tibetan situation is one in which "an authority in exile claims to be the government of a State which is under the effective control of a colonial power, a belligerent occupant or its local puppet, or an authority which came to power by coup d'etat or revolution." Id. at 8.

73. See TibetNet - Tibetan Government-in-Exile, at http://www.tibet.net/eng/tgie (last visited Oct. 2, 2001) [hereinafter TibetNet]. The Dalai Lama created the Central Tibetan Administration, which is the official name of the government-in-exile. See id.

74. See Senate Hearing, supra note 1 , at 79.

75. See TALMON, supra note 71, at 14-15.

76. See id. at 16. The term does not accord the government any special legal status. See id. at 15.

77. Recognition can be implied if States continue dealing with the newly elected government. See id. at 22 . Recognition can also signify an indication of willingness by a State to establish or maintain official relations with the government in question. See id. at 23 . Recognition or non-recognition can mean manifestation of a recognizing State's opinion that the government in question does exist legally. See id. at 29.

78. See id. at 14. Once other States recognize a government in a State, "they accord it the treatment attached to the same legal status, i.e. that of a government." Id.

79. See Radin, supra note 15 , at 699.

80. See TibetNet, supra note 73.

81. See id.

82. See id. The members of the judiciary are appointed by the Dalai Lama. See id.

83. See id. There are forty-six members of the legislature of which three are nominated by the Dalai Lama, and the legislature has local assemblies in thirty-eight Tibetan communities. See id.

84. See id. The Kashag consists of eight members and it is the highest executive body of the exiled community. See id. 
The Legislature adopted the Charter of the Tibetans in Exile as the exiled Tibetan community's Constitution. ${ }^{85}$ The preamble to the Charter provides:

Whereas His Holiness the Dalai Lama has offered a democratic system to Tibetans, in order that the Tibetan People in-Exile be able to preserve their ancient traditions of spiritual and temporal life, unique to the Tibetans, based on the principles of peace and non-violence, aimed at providing political, social and economic rights as well as the attainment of justice and equality for all Tibetan people. Whereas efforts shall be made to transform a future Tibet into a Federal Democratic Self-Governing Republic and a zone of peace throughout her three regions. Whereas in particular, efforts shall be made in promoting the achievement of Tibet's common goal as well as to strengthen the solidarity of Tibetans, both within and out of Tibet, and to firmly establish a democratic system, suitable to the temporary ideals of the Tibetan people; the Eleventh Assembly of Tibetan People's Deputies do hereby take over Legislative powers, promulgate and legalize this Charter of the Tibetans in-Exile as their fundamental guide. ${ }^{86}$

The Constitution is binding on all Tibetans, ${ }^{87}$ and it allows for local laws to conform to international law. ${ }^{88}$ Chapter Two of the Charter sets out the fundamental rights and duties of Tibetans. ${ }^{89}$

\section{SEVENTEEN POINT AGREEMENT ${ }^{90}$}

\section{A. Legality of the Agreement}

This Agreement should not be binding for a number of reasons. First,

85. See id. This Charter was adopted on June 14, 1991, and draws heavily on the Universal Declaration of Human Rights. See id.

86. ICL - Tibet - Constitution available at http://www.uniwuerzburg.de/law/t100000_.html (last visited Oct. 2, 2001) [hereinafter Tibetan Constitution].

87. See id. Article 2 provides: "This Charter shall be binding and enforceable to all Tibetans under the jurisdiction of the Tibetan Administration in-Exile." Id.

88. See id. Article 6 provides in part that all laws of the Tibetan Administration in-exile shall conform to the principles of international law and the local laws of the host countries. See Id.

89. See id. Article 9 sets out equality before the law. See id. Article 10 allows for religious freedom. See id. Article 11 allows for the right to vote and nomination of candidates for the assembly. See id. Article 12 sets out other fundamental rights and freedoms. See id. Article 13 sets out obligations of the citizens. See id.

90. For the history of the Seventeen Point Agreement, see supra notes 55-70 and accompanying text. 
it was signed while the armies of the People's Republic of China occupied Tibet. ${ }^{91}$ Second, the Tibetan representatives did not have authority to sign an agreement on behalf of the Tibetan people. ${ }^{92}$ Third, the Agreement was signed under the threat of possible military action. ${ }^{93}$ If a treaty is imposed by force or a country is threatened by the use of force into signing an agreement, then the agreement is void and is not binding upon the parties to the agreement. ${ }^{94}$ Tibet was already occupied by Chinese troops when it agreed to negotiate, ${ }^{95}$ which is in violation of international law. ${ }^{96}$ The Cabinet Minister, who was sent to negotiate with the Chinese as the chief negotiating representative, was unable to consult with the Cabinet or the Dalai Lama before concluding an agreement. $^{97}$ Due to the lack of authority and the threat of military advancement by the Chinese, this Agreement ${ }^{98}$ lacks legal authority under international law. 99

\section{B. Violations of the Agreement}

The Tibetans, through the Dalai Lama, repudiated this Agreement in 1959 following accusations that the Chinese breached the Agreement. ${ }^{100}$

91. See REPORT OF THE WORKSHOP ON SELF-DETERMINATION OF THE TIBETAN PEOPLE, TIBetan PEOPLE's Right Of SELF-DetERmination 16 (1996) [hereinafter REPORT].

92. See id.

93. See id.

94. See The Government of Tibet in Exile, Invasion and Illegal Annexation of Tibet: 1949-1951 at http://www.tibet.com/WhitePaper/white2.html (last visited Sept. 23, 2001) [hereinafter Illegal Annexation]. This view is indicated in the Vienna Convention on the Law of Treaties. See id. See also Proving, supra note 65, at 27. See Vienna Convention on the Law of Treaties at http://www.un.org/law/ilc/texts/treaties.htm (last visited Oct. 29, 2001). Article 49 states, "If a State has been induced to conclude a treaty by the fraudulent conduct of another negotiating State, the State may invoke the fraud as invalidating its consent to be bound by the treaty." Id. Article 50 states, "If the expression of a State's consent to be bound by a treaty has been procured through the corruption of its representative directly or indirectly by another negotiating State, the State may invoke such corruption as invalidating its consent to be bound by the treaty." Id. Article 51 states, "The expression of a State's consent to be bound by a treaty which has been procured by the coercion of its representative through acts or threats directed against him shall be without any legal effect." Id. Article 52 states, "A treaty is void if its conclusion has been procured by the threat or use of force in violation of the principles of international law embodied in the Charter of the United Nations." Id.

95. See Tibet.ca, supra note 56. Forty thousand Chinese troops occupied most of Tibet by 1951 . See id.

96. See id.

97. See id.

98. See REPORT, supra note 91 , at 108. The Tibetan delegation signed the agreement under force while also being under the impression that the Agreement could not limit the Dalai Lama's powers. See id.

99. See Tibet.ca, supra note 56.

100. See Tibet File No. 2: The Seventeen Point Agreement - May 1951 at http://www.freetibet.org/info/file2.htm (last visited Sept, 21, 2001) [hereinafter File No. 2]. See also Tibet.ca, supra note 56. The Dalai Lama could not repudiate the Agreement until he was safely in India. See id. 
Although the Tibetans do not recognize the Agreement, China promotes it as binding but fails to observe its provisions. ${ }^{101}$ Violations of the Agreement should be seen as releasing the Tibetan Government from its obligations under the Agreement, with the result being Tibet regaining previously surrendered sovereignty. ${ }^{102}$ The Chinese violated the Agreement when it instituted communist-style reforms and repressed the Tibetan peoples' religious freedoms. ${ }^{103}$

The Dalai Lama is the personal authority for the Tibetan people because he embodies all for which his land stands. ${ }^{104}$ The Chinese government's undermining of the Dalai Lama's authority is a step towards destroying the Tibetan way of life. ${ }^{105}$ The Chinese pledged to respect the Tibetans' separate way of life; ${ }^{106}$ however, the regional office located in Lhasa, Tibet, is a Chinese-controlled institution. ${ }^{107}$ In violation of Article Seven of the Agreement, ${ }^{108}$ the Chinese do not allow Tibetans to engage freely in their choice of religion. ${ }^{109}$ In violation of Articles Four ${ }^{110}$ and Eleven, ${ }^{111}$ the Chinese government decided to implement socialism ${ }^{112}$ in Tibet against the wishes of the Dalai

101. See Tibet.ca, supra note 56. See also Tibetinfo.net, supra note 70. Examples of China's failure to observe certain provisions of the Agreement include the violation of China's commitment not to alter Tibet's existing political system, not interfere with the status, function, and powers of the Dalai Lama or the Panchen Lama, allow regional autonomy to the Tibetans, and respect their religious beliefs and customs. See id.

102. See ICJ, supra note 3, at 17. China's violations are more than just a matter of domestic concern because it involves the existence of Tibet as a member of nations. See id.

103. See Kelly, supra note 55, at 270.

104. See ICJ, supra note 3, at 21.

105. See id.

106. See id. at 140. Article 3 of the Agreement states, "In accordance with the policy towards nationalities laid down in the Common Programme [sic] of the CPPCC, the Tibetan people have the right of exercising national regional autonomy under the unified leadership of the CPG." Id.

107. See id. at 21 . "Regional autonomy should mean more than co-operation; it should mean powers of initiative and decision." Id.

108. See id. at 140. Article 7 states:

The policy of freedom of religious belief laid down in the Common Programme [sic] of the CPPCC shall be carried out. The religious beliefs, customs and habits of the Tibetan people shall be respected and lama monasteries shall be protected. Id.

The central authorities will not effect a change in the income of the monasteries.

109. See infra notes $264-270$ and accompanying text.

110. See ICJ, supra note 3, at 140. Article 4 states, " The central authorities will not alter the existing political system in Tibet. The central authorities also will not alter the established status, functions and powers of the Dalai Lama. Officials of various ranks shall hold office as usual." Id.

111. See id. at 141. Article 11 states, "In matters related to various reforms in Tibet, there will be no compulsion on the part of the central authorities. The local government of Tibet should carry out reforms of its own accord, and, when the people raise demands for reform, they shall be settled by means of consultation with the leading personnel of Tibet." Id.

112. Socialism is

1: any of various economic and political theories advocating collective or governmental ownership and administration of the means of production and distribution of goods 
Lama. ${ }^{13}$

\section{HUMAN RighTS INSTRUMENTS}

\section{A. In General and the Charter of the United Nations}

China became a member of the United Nations on October 24, 1945, ${ }^{114}$ and ratified the Charter of the United Nations ${ }^{115}$ on September $28,1945 .{ }^{116}$ The purpose of the United Nations, as set out in the Charter, is to maintain international peace, develop friendly relations, achieve cooperation in solving problems, and to be the center of harmonization. ${ }^{117}$ The Charter requires

2: a: a system of society or group living in which there is no private property

b: a system or condition of society in which the means of production are owned and controlled by the state

3: a stage of society in Marxist theory transitional between capitalism and communism and distinguished by unequal distribution of goods and pay according to work done.

WEBSTER'S NINTH NEW COLEGIATE DiCTIONARY 1118 (9th ed. 1990).

113. See ICJ, supra note 3 at 48.

114. See List of Member States at http://www.un.org/Overview/unmember.html (last visited Sept. 6, 2001).

115. The preamble states:

WE THE PEOPLES OF THE UNITED NATIONS DETERMINED to save succeeding generations from the scourge of war, which twice in our lifetime has brought untold sorrow to mankind, and to reaffirm faith in fundamental human rights, in the dignity and worth of the human person, in the equal rights of men and women and of nations large and small, and to establish conditions under which justice and respect for the obligations arising from treaties and other sources of international law can be maintained, and to promote social progress and better standards of life in larger freedom, AND FOR THESE ENDS to practise [sic] tolerance and live together in peace with one another as good neighbours, [sic] and to unite our strength to maintain international peace and security, and to ensure, by the acceptance of principles and the institution of methods, that armed force shall not be used, save in the common interest, and to employ international machinery for the promotion of the economic and social advancement of all peoples. ...

U.N.CHARTER at http://www.unhchr.ch/html/menu3/b/ch-chp1 htm (last visited Oct. 29, 2001).

116. See Multilateral Treaties to Which China is a Party or Which China Has Signed at http://www.china-un.org/eng/premade/13561/Multilateral\%20Treaties.htm (last visited Sept. $5,2001)$.

117. Chapter I, Article 1 states: The Purposes of the United Nations are:

1. To maintain international peace and security, and to that end: to take effective collective measures for the prevention and removal of threats to the peace, and for the suppression of acts of aggression or other breaches of the peace, and to bring about by peaceful means, and in conformity with the principles of justice and international law, adjustment or settlement of international disputes or situations which might lead to a breach of the peace;

2. To develop friendly relations among nations based on respect for the principle of equal rights and self-determination of peoples, and to take other appropriate measures to strengthen universal peace; 
Members to fulfill obligations, settle disputes peacefully, refrain from the threat or use of force, and assist the United Nations in any action it takes. ${ }^{118}$

\section{B. Universal Declaration of Human Rights}

The Universal Declaration of Human Rights (UDHR) is not a binding instrument and is used to promote respect for human rights. ${ }^{19}$ The UDHR

3. To achieve international cooperation in solving international problems of an economic, social, cultural, or humanitarian character, and in promoting and encouraging respect for human rights and for fundamental freedoms for all without distinction as to race, sex, language, or religion; and

4. To be a center for harmonizing the actions of nations in the attainment of these common ends.

U.N. CHARTER, supra note 115.

118. Chapter I, Article 2 states: The Organization and its Members, in pursuit of the Purposes stated in Article 1, shall act in accordance with the following Principles.

1. The Organization is based on the principle of the sovereign equality of all its Members.

2. All Members, in order to ensure to all of them the rights and benefits resulting from membership, shall fulfill in good faith the obligations assumed by them in accordance with the present Charter.

3. All Members shall settle their international disputes by peaceful means in such a manner that international peace and security, and justice, are not endangered.

4. All Members shall refrain in their international relations from the threat or use of force against the territorial integrity or political independence of any state, or in any other manner inconsistent with the Purposes of the United Nations.

5. All Members shall give the United Nations every assistance in any action it take in accordance with the present Charter, and shall refrain from giving assistance to any state against which the United Nations is taking preventive or enforcement action.

6. The Organization shall ensure that states which are not Members of the United Nations act in accordance with these Principles so far as may be necessary for the maintenance of international peace and security.

7. Nothing contained in the present Charter shall authorize the United Nations to intervene in matters which are essentially within the domestic jurisdiction of any state or shall require the Members to submit such matters to settlement under the present Charter; but this principle shall not prejudice the application of enforcement measures under Chapter VII.

Id.

119. The Preamble states:

Whereas recognition of the inherent dignity and of the equal and inalienable rights of all members of the human family is the foundation of freedom, justice and peace in the world, Whereas disregard and contempt for human rights have resulted in barbarous acts which have outraged the conscience of mankind, and the advent of a world in which human beings shall enjoy freedom of speech and belief and freedom from fear and want has been proclaimed as the highest aspiration of the common people, Whereas it is essential, if man is not to be compelled to have recourse, as a last resort, to rebellion against tyranny and oppression, that human rights should be protected by the rule of law, Whereas it is essential to promote the development of friendly relations between nations, 
promotes equality among people, ${ }^{120}$ without distinction of any kind. ${ }^{121}$ The UDHR allows for the right to life, ${ }^{122}$ equal protection of the law, ${ }^{123}$ freedom to choose to marry, ${ }^{124}$ the right to move within the country and leave the country, ${ }^{125}$ and protection against unemployment. ${ }^{126}$ The UDHR opposes the

Whereas the peoples of the United Nations have in the Charter reaffirmed their faith in fundamental human rights, in the dignity and worth of the human person and in the equal rights of men and women and have determined to promote social progress and better standards of life in larger freedom, Whereas Member States have pledged themselves to achieve, in co-operation with the United Nations, the promotion of universal respect for and observance of human rights and fundamental freedoms, Whereas a common understanding of these rights and freedoms is of the greatest importance for the full realization of this pledge, Now Therefore THE GENERAL ASSEMBLY proclaims THIS UNIVERSAL DECLARATION OF HUMAN RIGHTS as a common standard of achievement for all peoples and all nations, to the end that every individual and every organ of society, keeping this Declaration constantly in mind, shall strive by teaching and education to promote respect for these rights and freedoms and by progressive measures, national and international, to secure their universal and effective recognition and observance, both among the peoples of Member States themselves and among the peoples of territories under their jurisdiction.

Universal Declaration of Human Rights at http://www.un.org/Overview/rights.html (last visited Sept. 6, 2001) [hereinafter UDHR].

120. Article 1 provides, "All human beings are bom free and equal in dignity and rights. They are endowed with reason and conscience and should act towards one another in a spirit of brotherhood." Id.

121. Article 2 provides in part, "Everyone is entitled to all the rights and freedoms set forth in the Declaration, without distinction of any kind, such as race, colour, [sic] sex, language, religion, political or other opinion, national or social origin, property, birth or other status." Id. Article 7 provides in part, "All are entitled to equal protection against any discrimination in violation of this Declaration and against any incitement to such discrimination." Id.

122. Article 3 provides, "Everyone has the right to life, liberty and security of person." Id.

123. Article 7 provides in part, "All are equal before the law and are entitled without any discrimination to equal protection of the law." Id.

124. Article 16 provides:

(1) Men and women of full age, without any limitation due to race, nationality or religion, have the right to marry and to found a family. They are entitled to equal rights as to marriage, during marriage and at its dissolution.

(2) Marriage shall be entered into only with the free and full consent of the intending spouses.

(3) The family is the natural and fundamental group unit of society and is entitled to protection by society and the State.

Id.

125. Article 13 provides, "(1) Everyone has the right to freedom of movement and residence within the borders of each state. (2) Everyone has the right to leave any country, including his own, and to return to his country." Id.

126. Article 23 provides:

(1) Everyone has the right to work, to free choice of employment, to just and favourable [sic] conditions of work and to protection against unemployment.

(2) Everyone, without any discrimination, has the right to equal pay for equal work. 
use of torture ${ }^{127}$ and arbitrary arrest. ${ }^{128}$ The Chinese are in violation of many of the human rights expressed in this Declaration. ${ }^{129}$

\section{Convention on the Elimination of All Forms of Racial Discrimination}

China became a member to the Convention on the Elimination of All Forms of Racial Discrimination (CERD) on December 29, 1981. ${ }^{130}$ The main objective of this Convention is to promote racial equality by providing special protections for certain racial and ethnic groups. ${ }^{131}$ The CERD covers indirect discrimination, which is also referred to as unjustified disparate impact. ${ }^{132}$ "[T]he term 'racial discrimination' shall mean any distinction, exclusion, restriction or preference based on race, colour [sic], descent, or national or ethnic origin which has the purpose ... of nullifying or impairing the ... enjoyment ... of human rights. ..."133

The CERD condemns racial discrimination and undertakes to pursue a policy that eliminates racial discrimination. ${ }^{134}$ It condemns propaganda and or-

(3) Everyone who works has the right to just and favourable [sic] remuneration ensuring for himself and his family an existence worthy of human dignity, and supplemented, if necessary, by other means of social protection.

(4) Everyone has the right to form and to join trade unions for the protection of his interests.

Id.

127. Article 5 provides, "No one shall be subjected to torture or to cruel, inhuman or degrading treatment or punishment." Id. Id.

128. Article 9 provides, "No one shall be subjected to arbitrary arrest, detention or exile."

129. See infra notes $\mathbf{1 8 0 - 2 8 8}$ and accompanying text.

130. See Office of the United Nations High Commissioner for Human Rights. Status of Ratifications of the Principal International Human Rights Treaties at http://www.unhchr.ch/pdf/report.pdf (last modified Oct. 22, 2001) [hereinafter Status of Ratifications].

131. See Intemational Convention on the Elimination of All Forms of Racial Discrimination, New York, 7 March 1966 at http://untreaty.un.org/English/Treaty Event2001/6.htm (last visited Oct. 5, 2001). "[This Convention] was the first human rights instrument to establish an international monitoring system and was also revolutionary in its provision of national measures towards the advancement of specific racial or ethnic groups." Id.

132. See id.

133. International Convention on the Elimination of All Forms of Racial Discrimination at http://www.unhehr.ch/html/menu3/b/d_icerd.htm (last visited Oct. 29, 2001) [hereinafter CERD].

134. Part I, Article 2 provides in part, " 1 . States Parties condemn racial discrimination and undertake to pursue by all appropriate means and without delay a policy of eliminating racial discrimination in all its forms and promoting understanding among all races...." Id. 
ganizations that promote discrimination, ${ }^{135}$ guarantees the right of equality, ${ }^{136}$ assures effective protection and remedies, ${ }^{137}$ and undertakes to adopt measures that combat racial discrimination. ${ }^{138}$

\section{Convention Against Torture and Other Cruel, Inhuman or Degrading Treatment or Punishment}

China became a member to the Convention Against Torture and Other Cruel, Inhuman or Degrading Treatment or Punishment (CAT) on October 4, 1988. ${ }^{139}$ Torture and other cruel treatments are strictly condemned by the international world because of the seriousness of the violations. ${ }^{140}$ The prohibition against torture ${ }^{141}$ is absolute and no circumstances can justify the

135. Part I, Article 4 provides in part, "States Parties condemn all propaganda and all organizations which are based on ideas or theories of superiority of one race or group of persons of one colour [sic] or ethnic origin, or which attempt to justify or promote racial hatred and discrimination in any form. ..." Id.

136. Part I, Article 5 provides in part: States Parties undertake to prohibit and to eliminate racial discrimination in all its forms and to guarantee the right of everyone, without distinction as to race, colour [sic], or national or ethnic origin, to equality before the law, notably in the enjoyment of the following rights:

(a) The right to equal treatment before the tribunals and all other organs administering justice;

(b) The right to security of person and protection by the State against violence or bodily harm, whether inflicted by government officials or by any individual group or institution;

(c) Political rights, in particular the right to participate in elections-to vote and to stand for election-on the basis of universal and equal suffrage, to take part in the Government as well as in the conduct of public affairs at any level and to have equal access to public service;

(d) Other civil rights;

(e) Economic, social and cultural rights;

(f) The right of access to any place or service intended for use by the general public, such as transport hotels, restaurants, cafes, theatres and parks.

Id.

137. Part I, Article 6 provides in part, "States Parties shall assure to everyone within their jurisdiction effective protection and remedies. . .against any acts of racial discrimination which violate his human rights and fundamental freedoms contrary to this Convention. ..." Id.

138. Part I, Article 7 provides in part, "States Parties undertake to adopt immediate and effective measures, with a view to combating prejudices which lead to racial discrimination and to promoting understanding, tolerance and friendship among nations and racial or ethical groups..."Id.

139. See Status of Ratifications, supra note 130.

140. See Convention Against Torture and Other Cruel, Inhuman or Degrading Treatment or Punishment, New York, 10 December 1984 at http://untreaty.un.org/English/Treaty Event2001/7.htm (last visited Oct. S, 2001) [hereinafter CAT website].

141. Part I, Article 1 provides in part the definition of torture.

[T] he term 'torture' means any act by which severe pain or suffering, whether physical or mental, is intentionally inflicted on a person for such purposes as obtaining from him or a third person information or a confession, punishing him for an act he or a third person has committed or is suspected of having committed, or intimidating or coercing him or a third person, or for any reason 
invocation of torture. ${ }^{142}$

States parties must take effective measures to prevent acts of torture from occurring in their State ${ }^{143}$ and must not extradite a person to another State where he or she would be in danger of being subjected to torture. ${ }^{144}$ Under CAT, law enforcement personnel are properly trained regarding the prohibition against torture, ${ }^{145}$ and torture shall be considered a criminal offense ${ }^{146}$ to which the victim has redress. ${ }^{147}$

\section{E. International Covenant on Civil and Political Rights}

China became a signatory to the International Covenant on Civil and Political Rights (CCPR) on October 5, 1998. ${ }^{148}$ The CCPR promotes human

based on discrimination of any kind, when such pain or suffering is inflicted by or at the instigation of or with the consent or acquiescence of a public official or other person acting in an official capacity. It does not include pain or suffering arising only from, inherent in or incidental to lawful sanctions.

Convention Against Torture and Other Cruel, Inhuman or Degrading Treatment or Punishment at http://www.unhchr.ch/html/menu3/b/h_cat39.htm (Sept. 6, 2001) [hereinafter CAT].

142. See CAT website, supra note 140.

143. Part I, Article 2 provides in part:

1. Each State Party shall take effective legislative, administrative, judicial or other measures to prevent acts of torture in any territory under its jurisdiction.

2. No exceptional circumstances whatsoever, whether a state of war or a threat of war, internal political in stability [sic] or any other pubic emergency, may be invoked as a justification of torture.

CAT, supra note 141.

144. Part I, Article 3 provides in part, "1. No State Party shall expel, return ("refouler") or extradite a person to another State where there are substantial grounds for believing that he would be in danger of being subjected to torture." Id. The UN states as a key provision that:

States parties have the obligation to prevent and punish not only acts of torture as defined in the Convention, but also other acts of cruel, inhuman or degrading treatment or punishment, when such acts are committed by or at the instigation of or with the consent or acquiescence of a public official or other person acting in an official capacity.

See CAT website, supra note 140.

145. Part I, Article 10 provides in part:

1. Each State Party shall ensure that education and information regarding the prohibition against torture are fully included in the training of law enforcement personnel, civil or military, medical personnel, public officials and other persons who may be involved in the custody, interrogation or treatment of any individual subjected to any form of arrest, detention or imprisonment.

CAT, supra note 141.

146. Part I, Article 4 provides in part, "1. Each State Party shall ensure that all acts of torture are offences [sic] under its criminal law." Id.

147. Part I, Article 14 provides in part, "1. Each State Party shall ensure in its legal system that the victim of an act of torture obtains redress and has an enforceable right to fair and adequate compensation, including the means for as full rehabilitation as possible." Id.

148. See Status of Ratifications, supra note 130. 
rights and defends the right to life. ${ }^{149}$

The CCPR provides for the right to self-determination, ${ }^{150}$ the right to life, ${ }^{151}$ the right to liberty, ${ }^{152}$ the right to move around within and outside the state, ${ }^{153}$ the right to be presumed innocent, ${ }^{154}$ the right to be recognized as a person, ${ }^{155}$ the right to freedom of thought and religion, ${ }^{156}$ the right to hold opinions ${ }^{157}$ and the right for every child to be registered. ${ }^{158}$ The CCPR does not allow for discrimination ${ }^{159}$ or torture of any kind. ${ }^{160}$

149. See International Covenant on Civil and Political Rights, New York, 16 December 1966 at http://untreaty.un.org/English/TreatyEvent2001/9.htm (last visited Oct. 5, 2001) [hereinafter CCPR website]. The CCPR "stipulates that no individual can be subjected to torture, enslavement, forced labour [sic] and arbitrary detention or be restricted from such freedoms as movement, expression and association." Id.

150. Part I, Article 1 provides in part, "All peoples have the right of self-determination. By virtue of that right they freely determine their political status and freely pursue their economic, social and cultural development." International Covenant on Civil and Political Rights at http://www.unhchr.ch/html/menu3/b/a_ccpr.htm (last visited Sept. 6, 2001) [hereinafter CCPR].

151. Part III, Article 6 provides in part, " 1 . Every human being has the inherent right to life. This right shall be protected by law. No one shall be arbitrarily deprived of his life." Id.

152. Part III, Article 9 provides in part:

1. Everyone has the right to liberty and security of person. No one shall be subjected to arbitrary arrest or detention. No one shall be deprived of his liberty except on such grounds and in accordance with such procedure as are established by law.

2. Anyone who is arrested shall be informed, at the time of arrest, of the reasons for his arrest and shall be promptly informed of any charges against him.

3. Anyone arrested or detained on a criminal charge shall be brought promptly before a judge or other officer authorized by law to exercise judicial power and shall be entitled to trial within a reasonable time or to release.

Id. Part III, Article 10 provides in part, "1. All persons deprived of their liberty shall be treated with humanity and with respect for the inherent dignity of the human person." Id.

153. Part III, Article 12 provides in part, " 1 . Everyone lawfully within the territory of a State shall, within that territory, have the right to liberty of movement and freedom to choose his residence. 2. Everyone shall be free to leave any country, including his own." Id.

154. Part III, Article 14 provides in part, " 2 . Everyone charged with a criminal offence [sic] shall have the right to be presumed innocent until proved guilty according to law." Id.

155. Part III, Article 16 provides, "Everyone shall have the right to recognition everywhere as a person before the law." Id.

156. Part III, Article 18 provides in part, "1. Everyone shall have the right to freedom of thought, conscience and religion... 2. No one shall be subject to coercion which would impair his freedom to have or to adopt a religion or belief of his choice." Id.

157. Part III, Article 19 provides in part, "1. Everyone shall have the right to hold opinions without interference. 2. Everyone shall have the right to freedom of expression." Id.

158. Part III, Article 24 provides in part, "2. Every child shall be registered immediately after birth and shall have a name." Id. See also infra note 202 and accompanying text.

159. Part II, Article 2 provides in part:

1. Each State Party to the present Covenant undertakes to respect and to ensure to all individuals within its territory and subject to its jurisdiction the rights recognized in the present Covenant, without distinction of any kind, such as race, colour [sic], sex, language, religion, political or other 


\section{F. International Covenant on Economic, Social and Cultural Rights}

China became a member to the International Covenant on Economic, Social and Cultural Rights (CESCR) on March 27, 2001. ${ }^{161}$ The CESCR "provides the most important international legal framework for protecting basic human rights." 162

The CESCR grants many rights, ${ }^{163}$ including the right of selfdetermination, ${ }^{164}$ the right to work, ${ }^{165}$ the right to a sufficient standard of living, ${ }^{166}$ and the right to an education. ${ }^{167}$

\section{G. Convention on the Rights of the Child}

China became a member to the Convention on the Rights of the Child (CRC) on March 3, 1992. ${ }^{168}$ This is a legally binding instrument that provides

ld.

opinion, national or social origin, property, birth or other status.

160. Part III, Article 7 provides in part, "No one shall be subjected to torture or to cruel, inhuman or degrading treatment or punishment." Id.

161. See Status of Ratifications, supra note 130.

162. International Covenant on Economic, Social and Cultural Rights, New York, 16 December 1966 at http://untreaty.un.org/English/TreatyEvent2001/8.html (last visited Oct. 5, 2001) [hereinafter CESCR website].

163. For a list of protected rights, see generally id.

164. Part I, Article 1 provides in part, " 1 . All peoples have the right of self-determination. By virtue of that right they freely determine their political status and freely pursue their economic, social and cultural development." International Covenant on Economic, Social and Cultural Rights at http://www.unhchr.ch/html/menu3/b/a_cescr.html (last visited Oct. 29, 2001) [hereinafter CESCR].

165. Part III, Article 6 provides in part, "1. The States Parties to the present Covenant recognize the right to work, which includes the right of everyone to the opportunity to gain his living by work which he freely chooses or accepts, and will take appropriate steps to safeguard this right." Id.

166. Part III, Article 11 provides in part, "1. The States Parties to the present Covenant recognize the right of everyone to an adequate standard of living for himself and his family, including adequate food, clothing and housing, and to the continuous improvement of living conditions." Id.

167. Part III, Article 13 provides in part:

1. The States Parties to the present Covenant recognize the right of everyone to education. They agree that education shall be directed to the full development of the human personality and the sense of its dignity, and shall strengthen the respect for human rights and fundamental freedoms. They further agree that education shall enable all persons to participate effectively in a free society, promote understanding, tolerance and friendship among all nations and all racial, ethnic or religious groups, and further the activities of the United Nations for the maintenance of peace.

Id.

168. See Status of Ratifications, supra note 130. 
for the protection of children's rights. ${ }^{169}$ The key provisions of the CRC focus on non-discrimination, the best interests of children, the right to life, survival and development, and the views of the children. ${ }^{170}$

Under the CRC, a child is one who has not yet attained the age of eighteen years. ${ }^{171}$ This instrument ensures that children have the right to life, ${ }^{172}$ that they are registered and acquire a nationality, ${ }^{173}$ the right to express their own views, ${ }^{174}$ the right to particular freedoms, such as thought and religion, ${ }^{175}$ the right to education, ${ }^{176}$ the right to enjoy his or her own culture

169. See Convention on the Rights of the Child, New York, 20 November 1989, at http://untreaty.un.org/English/TreatyEvent2001/3.htm (last visited Oct. 5, 2001) [hereinafter CRC website]. This Convention is the most rapidly and widely ratified human rights instrument throughout the world. See id.

170. See id.

171. Part I, Article 1 provides in part, "[A] child means every human being below the age of eighteen years unless under the law applicable to the child, majority is attained earlier." Convention on the Rights of the Child at http://www.unhchr.ch $/ \mathrm{html} / \mathrm{menu} 3 / \mathrm{b} / \mathrm{k} 2 \mathrm{crc}$.htm (last visited Oct. 29, 2001) [hereinafter CRC].

172. Part I, Article 6 provides, " 1 . States Parties recognize that every child has the inherent right to life. 2. States Parties shall ensure to the maximum extent possible the survival and development of the child." Id.

173. Part I, Article 7 provides in part, "The child shall be registered immediately after birth and shall have the right from birth to a name, the right to acquire a nationality and as far as possible, the right to know and be cared for by his or her parents." Id.

174. Part I, Article 12 provides:

1. States Parties shall assure to the child who is capable of forming his or her own views the right to express those views freely in all matters affecting the child, the views of the child being given due weight in accordance with the age and maturity of the child.

2. For this purpose, the child shall in particular be provided the opportunity to be heard in any judicial and administrative proceedings affecting the child, either directly, or through a representative or an appropriate body, in a manner consistent with the procedural rules of national law.

Id.

175. Part I, Article 14 provides in part, " 1 . States Parties shall respect the right of the child to freedom of thought, conscience and religion." Id.

176. Part I, Article 28 provides:

1. States Parties recognize the right of the child to education, and with a view to achieving this right progressively and on the basis of equal opportunity, they shall, in particular:

(a) Make primary education compulsory and available free to all;

(b) Encourage the development of different forms of secondary education ... make them available and accessible to every child, and take appropriate measures such as the introduction of free education and offering financial assistance in,case of need;

(c) Make higher education accessible to all on the basis of capacity by every appropriate means;

(d) Make educational and vocational information and guidance available and accessible to all children;

(e) Take measures to encourage regular attendance at schools and the reduction of drop-out rates.

2. States Parties shall take all appropriate measures to ensure that school discipline is administered in a manner consistent with the child's human 
if a member of a minority group, ${ }^{177}$ and ensures that children are not subjected to torture. ${ }^{178}$ This Convention works as a useful tool for society working for the protection and promotion of children's rights. ${ }^{179}$

\section{Human Rights Violations Since ChINeSe Occupation}

\section{A. General Discussion About Human Rights Violations}

China argues that the issue of human rights violations ${ }^{180}$ in Tibet is an

Id.

dignity and in conformity with the present Convention.

3. States Parties shall promote and encourage international cooperation in matters relating to education, in particular with a view to contributing to the elimination of ignorance and illiteracy throughout the world and facilitating access to scientific and technical knowledge and modern teaching methods.

177. Part I, Article 30 provides:

In those States in which ethnic, religious or linguistic minorities or persons of indigenous 'origin exist, a child belonging to such a minority or who is indigenous shall not be denied the right, in community with other members of his or her group, to enjoy his or her own culture, to profess and practise [sic] his or her own religion, or to use his or her own language.

Id.

178. Part I, Article 37 provides in part: States Parties shall ensure that:

(a) No child shall be subjected to torture or other cruel, inhuman or degrading treatment or punishment.

(b) No child shall be deprived of his or her liberty unlawfully or arbitrarily. The arrest, detention or imprisonment of a child shall be in conformity with the law and shall be used only as a measure of last resort and for the shortest appropriate period of time;

(c) Every child deprived of liberty shall be treated with humanity and respect for the inherent dignity of the human person, and in a manner which takes into account the needs of persons of his or her age.

(d) Every child deprived of his or her liberty shall have the right to prompt access to legal and other appropriate assistance, as well as the right to challenge the legality of the deprivation of his or her liberty before a court or other competent, independent and impartial authority, and to a prompt decision on any such action.

Id.

179. See CRC website, supra note 169.

180. The rights denied to the Tibetans include:

1. Life, liberty and security have been violated.

2. Forced labour [sic] has been inflicted on the Tibetans.

3. Torture and cruel and degrading treatment have been inflicted.

4. Rights of home and privacy have been violated.

5. Freedom of movement within a state, and the right to leave and return to Tibet have been denied.

6. Marriages have been forced upon unwilling parties.

7. Property rights have been arbitrarily violated.

8. Freedom of religion and worship have been systematically denied.

9. Freedom of the expression and communication of ideas is totally lacking.

10. Freedom of association is denied. 
internal matter and any foreign concern or criticism regarding these abuses is a violation of China's sovereignty. ${ }^{181}$ Some human rights violations that are occurring in Tibet are: violations of children's rights; discrimination of the Tibetan people; suppression of religious freedom; population control; torture; and arbitrary arrest and detention. ${ }^{182}$ Since China has invaded Tibet, the Chinese have undertaken a campaign of abuses against Tibetans and destroyed the traditional Tibetan culture. ${ }^{183}$

"[T]he U.S. Congress has persistently called on the executive branch to support Tibetan self-determination and to link aid to China with human rights improvements in Tibet." 184 The United States' concerns about the human rights abuses occurring in Tibet is superceded by its desire to maintain civilized relations with China. ${ }^{185}$

\section{B. Population Control ${ }^{186}$}

International law allows a person to have the right to find a family, ${ }^{187}$ and the Fourth Geneva Convention of 1949 makes it illegal for an occupying power to transfer civilians into the area being occupied. ${ }^{188}$ The Chinese government is inundating Tibet with Chinese settlers ${ }^{189}$ through a policy

11. The right to representative government is denied.

12. There is a wanton disregard for the economic rights of man in relation to his country's resources.

13. The right to a free choice of employment is denied.

14. Conditions of labour [sic] do not conform to minimum standards in respect of rest and limitations of hours.

15. The right to an adequate standard of living is denied.

16. The right to a liberal and efficient, non-discriminatory educational system is denied.

17. The right to participate in the cultural life of the community is denied.

18. The limitations imposed on the rights of the Tibetans far exceed any which are reasonably referable to the requirements of public morality, public order and the welfare of society.

ICJ, supre note 3, at 58-59.

181. See Asia Watch Report, Merciless Repression: Human RightS IN TIBET 2 (1990).

182. See infra notes $218-288$ and supra note 175 and accompanying text.

183. See Petersen, supra note 5, at 900.

184. Radin, supra note 15 , at 700.

185. See Petersen, supra note 5, at 901.

186. For a discussion on population transfer see generally Eric Kolodner, Population Transfer: The Effects of Settler Infusion Policies on a Host Population's Right to SelfDetermination, 27 N.Y.U. J. INT'L L. \& POL. 159 (1994).

187. See UDHR, supra note 119. Article 16(1), provides "Men and women of full age, without any limitation due to race . . have the right to marry and to found a family." Id. Article 16(3) states, "The family is the natural and fundamental group unit of society and is entitled to protection by society and the State." Id.

188. See Proving, supra note 65 , at 83.

189. See Radin, supra note 15 , at 698 . This effectively dilutes the Tibetan population. See id. 
known as population transfer. ${ }^{190}$ This is a major threat to the Tibetan population because the policy is curtailing its growth. ${ }^{191}$

Population transfer "allows China to degrade cultural rights in the name of economic expansion." 192 The Chinese encourage population transfer because they feel that the Tibet Autonomous Region's (TAR) population is inadequate to develop Tibet's resources. ${ }^{193}$ The Eastern Tibetan regions outside of the TAR have the highest concentration of Chinese settlers. ${ }^{194}$ In 1992, China opened Tibet's economy to foreign investments, a move which was designed to encourage more Chinese to settle in Tibet. ${ }^{195}$ Because of China's push toward population transfer, the Tibetans are inferior in "economic, political, educational and social spheres." 196

Coercive birth control measures ${ }^{197}$ are also being used to slow the growth of the Tibetan population. ${ }^{198}$ Tibetan couples are only allowed to have two children. ${ }^{199}$ If the Tibetans have more than two children, up to fifty percent of the worker's pay can be cut and the children are denied ration cards, ${ }^{200}$ also known as residence cards. ${ }^{201}$ The Chinese employ several measures to reduce the number of births, including sterilization ${ }^{202}$ and abortion. ${ }^{203}$ The

190. See Proving, supra note 65 , at 83 . "The aim of this ... policy is to ensure that the Tibetans are reduced to an insignificant minority in their own country so as to render any resistance against China's rule ineffective." Id. For a short discussion on population transfer, see generally ASIA WATCH REPORT, supra note 181.

191. See Proving, supra note 65 , at 83.

192. Radin, supra note 15 , at 713 . Tibetans are not involved in the development of their region and population transfer has ensured that the Tibetans do not receive any direct benefit of economic growth. See id.

193. See PROVING, supra note 65 , at 84.

194. See id. at 86 . These areas were settled soon after the invasion of the Chinese troops in 1949. See id.

195. See id. at 87.

196. Id. at 90 . The Chinese settlers have been given the most fertile land within Tibet. See id.

197. For testimonials regarding coercive birth control measures see generally THE TIBETAN WOMEN'S ASSOCIATION, TEARS OF SILENCE: A REPORT ON TIBETAN WOMEN AND POPULATION CONTROL (1995) app. A at 45-59. See also THE TIBETAN WOMEN's ASSOCIATION, TEARS OF SILENCE: A REPORT ON TIBETAN WOMEN AND POPULATION CONTROL (1995) Excerpts from "The Temporary Method for the Management of Planned Birth in the Tibet Autonomous Region." (Draft, Version 1, 8 May, 1992) app. B at 60-65.

198. See Proving, supra note 65 , at 83.

199. See id. at 87. This policy was instituted in 1984. See id.

200. See id. at 88.

201. See TIBETAN WOMEN's Association, supra note 197, at 16. Children who do not receive a residence card will have difficulty in "obtaining state-provided schooling, housing, basic foodstuffs, medical treatment and travel." Id. The children may also be denied certain political rights, such as voting and citizenship. See id.

202. See PROVING, supra note 65, at 88 . Nineteen percent of women in the TAR were sterilized in 1986. See id. In the Gansu Parig District, eighty-two percent of the women sterilized were Tibetan. See id.

203. See id. Teams roam the countryside rounding up women for abortions, and even those who are advanced in their pregnancy are forced to have an abortion and then be sterilized. See $i d$. at 88-89. See also TIBETAN WOMEN's AsSOCIATION, supra note 197, at 24 . When a woman 
enforcement of these measures differs from place to place because the Chinese officials are given complete discretion to implement these policies. ${ }^{204}$ By imposing these coercive birth control measures, China is violating the Convention on the Elimination of All Forms of Discrimination Against Women (CEDAW) ${ }^{205}$ The CEDAW condemns discrimination and allows for the undertaking of certain acts that will eliminate the discrimination against women. ${ }^{206}$ The CEDAW also ensures the development and advancement of women, ${ }^{207}$ access to family planning advice, ${ }^{208}$ access to health care services, ${ }^{209}$

seeks assistance at a public hospital but does not have the birth document, another form of abortion called infanticide, usually occurs by lethal injection into the soft spot on the head. See id.

204. See Proving, supra note 65 , at 89.

205. See Status of Ratifications, supra note 130 . China became a party to the CEDAW on November 4, 1980. See id. Article 16(1)(e) states women have "the same rights to decide freely and responsibly on the number and spacing of their children and to have access to the information, education and means to exercise these rights." Convention on the Elimination of All Forms of Discrimination Against Women at http://www.unhchr.ch/html/menu3/ b/elcedaw.htm (last visited Oct. 29,2001) [hereinafter CEDAW]. For a discussion on laws and conventions relating to population and women, see generally TIBETAN WOMEN'S ASSOCLATION, supra note 197.

206. Part I, Article 2 provides in part:

States Parties condemn discrimination against women in all its forms, agree to pursue by all appropriate means and without delay a policy of eliminating discrimination against women and, to this end, undertake:

(b) To adopt appropriate legislative and other measures, including sanctions where appropriate, prohibiting all discrimination against women;

(c) To establish legal protection of the rights of women on an equal basis with men and to ensure through competent national tribunals and other public institutions the effective protection of women against any act of discrimination;

(d) To refrain from engaging in any act or practice of discrimination against women and to ensure that public authorities and institutions shall act in conformity with this obligation;

(f) To take all appropriate measures, including legislation, to modify or abolish existing laws, regulations, customs and practices which constitute discrimination against women.

CEDAW, supra note 205.

207. Part I, Article 3 provides:

States Parties shall take in all fields, in particular in the political, social, economic and cultural fields, all appropriate measures, including legislation, to ensure the full development and advancement of women, for the purpose of guaranteeing them the exercise and enjoyment of human rights and fundamental

ld. freedoms on a basis of equality with men.

208. Part III, Article 10 provides in part, "(h) Access to specific educational information to help ensure the health and well-being of families, including information and advice on family planning." Id.

209. Part III, Article 12 provides:

1. States Parties shall take all appropriate measures to eliminate discrimination against women in the field of health care in order to ensure, on a basis of equality of men and women, access to health care services, including those related to family planning. 
and rights equal with men in making familial decisions. ${ }^{210}$

China implemented The Maternal and Infant Health Care Law in 1994, which gave the government the right to control marriages and births. ${ }^{211}$ These policies are not only enforced by physical force but also by economic force. ${ }^{212}$ The Chinese government has implemented a quota system to enforce birth control campaigns in Tibet. ${ }^{213}$ An example of a quota system implemented by the State is one that gives a population control target and point system, with the following items being examined: 1) number of births; 2) planned birth rate; 3) spread of two children; and 4) extra plan pregnancy rate. ${ }^{214}$ For those meeting the target, officials are given monetary awards, and those who do not meet the target will be criticized and even be demoted or dismissed. ${ }^{215}$ These implementations not only violate the CEDAW, but they violate Articles Six and Seven of the CRC ${ }^{216}$ and Articles Five and Sixteen of the UDHR. ${ }^{217}$

\section{Violations of Children's Rights}

Many children are subject to detention and torture if the Chinese suspect that the child may be involved in Tibetan nationalist activities, such as peaceful demonstrations. ${ }^{218}$ This is in violation of the most elementary human

2. Notwithstanding the provisions of paragraph $\mathbf{I}$ of this article, States Parties shall ensure to women appropriate services in connection with pregnancy, confinement, and the post-natal period, granting free services where necessary, as well as adequate nutrition during pregnancy and lactation.

Id.

210. Part IV, Article 16 provides in part:

1. States Parties shall take all appropriate measures to eliminate discrimination against women in all matters relating to marriage and family relations and in particular shall ensure, on a basis of equality of men and women:

(d) The same rights and responsibilities as parents, irrespective of their marital status, in matters relating to their children; in all cases the interest of the children shall be paramount;

(e) The same rights to decide freely and responsibly on the number and spacing of their children and to have access to the information, education and means to enable them to exercise these rights.

Id.

211. See Tibetan Women's Association, supra note 197, at 17. This law avoids breeding of inferior quality by allowing the use of sterilization and abortion and bans marriages to prevent the passing of mental disabilities and disease to children. See id.

212. See id. at 26.

213. See id. at 28. Doctors are given quotas that must be attained each year and each official's performance is measured based on whether they reach the quota. See id.

214. See id. at 29.

215. See id. at 30.

216. See CRC, supra notes $172-173$ and accompanying text.

217. See UDHR, supra note 124 and accompanying text.

218. See INTERNATIONAL COMMITTEE OF LAWYERS FOR TIBET, A GENERATION IN PERIL: THE Lives of TIBETAN CHILDREN UNDER CHINESE RULE 18 (2001) [hereinafter ICLT]. This torture usually consists of beatings with metal rods, electric shock, forced labor, deprivation of 
rights standards. ${ }^{219}$ Children are entitled to special protection because of their age. ${ }^{220}$ Children should be afforded due process, presumed innocent until proven guilty, informed of their charges, and be granted legal counsel. ${ }^{221}$

Tibetan.children are usually detained for one of three reasons. ${ }^{222}$ They are detained for participating in any act that can be construed as political, for attempting to flee the country, or for engaging in much more trivial activities, such as insubordination. ${ }^{223}$ Prisons and reform through labor centers, Reeducation through labor centers and Public Security Bureau centers are three different types of detention facilities where the police send children. ${ }^{224}$ Even though the law details the appropriate location for detention, most children who are sentenced administratively serve their sentences in the Public Security Bureau, which allows the police to exercise long-term authority over the detainees. ${ }^{225}$ Re-education through labor ${ }^{226}$ authorizes sentences of a period of three years to be handed down by "quasi-judicial government committees."227 This type of detention violates international law because it constitutes arbitrary detention. $^{228}$

Torture is used to obtain information or to intimidate detained children. 229 The most common forms of torture are electric shocks or beatings. ${ }^{230}$ Older girls are raped and more commonly, sexually assaulted as a means of torture. ${ }^{231}$ Torture is not only employed in detention centers, but also in schools in the form of corporal punishment. ${ }^{232}$ The most common form of corporal punishment is beatings, which in some cases causes cuts that

nutrients, and suspension in painful positions. See id.

219. See id. at 19.

220. See id.

221. See id. at 20. Tibetan children are arbitrarily detained without any due process and without giving them access to counsel or relatives or allowing them to have a legal hearing regarding their detention. See id. at 1.

222. See id. at 22.

223. See id. Children that are detained for fleeing are confined for a shorter period of time than those detained for political activity. See id. at 27.

224. See id. at 22. Prisons and reform through labor centers hold prisoners who are sentenced criminally; Re-education through labor centers hold prisoners who have been sentenced administratively; and Public Security Bureau detention centers are for prisoners being held for police investigations. See id.

225. See id. at 23. This type of detention allows for the greater possibility of torture due to the lack of accountability. See id.

226. See id. at 23-24. This is a form of administrative detention, which is in violation of international law and constitutes arbitrary detention. See id.

227. Id. Judicial authority does not authorize administrative detention; therefore, many authorities detain citizens for indefinite periods. See id. at 24.

228. See id.

229. See id. at 33.

230. See id.

231. See id. at 36.

232. See id. at 37. Teachers employ corporal punishment, rising to the level of torture, in primary schools located in Tibet. See id. Not only are the children physically tortured, but they are also publicly humiliated and subjected to acts of degrading treatment. See id. 
require stitches. ${ }^{233}$ These acts of corporal punishment and torture violate obligations under the Convention Against Torture. ${ }^{234}$ These acts are also in violation of the $\mathrm{UDHR}^{235}$ and the CRC. ${ }^{236}$

\section{Discrimination}

The occupation of Tibet by China is the main cause of racial discrimination ${ }^{237}$ against Tibetans. ${ }^{238}$ Although China acceded to the CERD in 1981, racial discrimination, which is still prevalent throughout Tibet, is the source of poor education and employment opportunities for Tibetans. ${ }^{239}$ In view of the fact that Tibetans are considered ethnic minorities, international law entitles them to better educational rights. ${ }^{240}$

China acceded to the CERD; therefore, they have an obligation to guarantee the right of everyone to equality before the law in the enjoyment of the right to education. ${ }^{241}$ One form of discrimination in education is the difficulty for Tibetan children to access education. ${ }^{242}$ This is in violation of the Convention on the Rights of the Child, which allows for the development of the child. ${ }^{243}$ There are many reasons why Tibetan children have difficulty accessing education. ${ }^{244}$ First, Tibetan educational facilities are inadequate in number and sophistication as compared to Chinese schools, ${ }^{245}$ and Tibetan schools receive less government funding. ${ }^{246}$ Educational reforms shifted financial responsibility from the central government to the local government,

233. See id. at 38.

234. See id. at 41.

235. See UDHR, supra notes 127,128 and accompanying text.

236. See CRC, supra notes $174,175,178$ and accompanying text.

237. For a general discussion on discrimination see generally PROVING, supra note 65. See also, ASIA WATCH REPORT, supra note 181.

238. See DEPARTMENT OF INFORMATION AND INTERNATIONAL RELATIONS, RACIAL DISCRIMINATION IN CHINESE-OCCUPIED TIBET 4 (2001) [hereinafter RACIAL DISCRIMINATION REPORT].

239. See id. at 5 .

240. See ICLT, supra note 218 , at 45.

241. See RACIAL DISCRIMINATION REPORT, supra note 238, at 7. See also CERD, supra note 133. Article $5(\mathrm{e})(\mathrm{v})$ provides, "The right to education and training." Id.

242. See RACIAL DISCRIMINATION REPORT, supra note 238 , at 8 . China concedes that approximately one-third of Tibetan children do not receive an education; whereas the number of Chinese children who do not receive education is only one and a half percent. See id. This causes a great disparity in literacy rates where nine percent of Chinese adults are illiterate compared to sixty percent of Tibetan adults. See id.

243. See CRC supra note 171 and accompanying text.

244. See RACIAL DISCRIMINATION REPORT, supra note 238, at 9.

245. See id. at 8-9. China directs most financial assistance to the urban areas of Tibet because they consist mainly of Chinese settlers. See id. at 9 .

246. See id. at 9. "The Chinese schools had computers and a science laboratory whereas the Tibetan school was heated by fire and didn't even have a playground." Id. 
causing the poorest areas to have the least amount of funds at their disposal. ${ }^{247}$ Second, Tibetans are charged fees to attend school. ${ }^{248}$ Third, access for Tibetan children may be restricted based upon the parents' ability to pay bribes $^{249}$ or their parents' connections with school officials. ${ }^{250}$

Another form of discrimination is the inability of Tibetans to learn about their culture and to practice their native language. ${ }^{251}$ The primary goal of education in China is to secure the Tibetans loyalty to the Chinese political movement rather than to educate toward the child's well-being. ${ }^{252}$ This monitoring of education by the Chinese government has led to a "suppression of Tibetan culture and history in the education curricula." 253 Since Tibetans are deemed a minority nationality, "international law obliges [China] to permit every Tibetan child 'to enjoy his or her own culture, to profess and practice his or her own religion, or to use his or her own language." 254 The urban population, which gets most of the financial assistance for education, consists mainly of Chinese settlers, while eighty percent of the Tibetan population lives in the rural areas, which do not receive as much financial assistance. ${ }^{255}$ However, teachers and other school officials discriminate against Tibetan children who attend mixed schools. ${ }^{256}$

Tibetans also suffer from employment discrimination, which is shown by the underrepresentation of Tibetans in certain business areas as well as disparities in working conditions between Chinese and Tibetans. ${ }^{257}$ This is in

247. See ICLT, supra note 218 , at 47 . Because of these policies, the educational gap has widened between the Tibetan people and the Chinese people. See id.

248. See id. at 49. Chinese law prohibits charging fees to attend school; however, it does permit and the Chinese government does charge miscellaneous fees, which makes it harder for Tibetan children to attend school. See id. at 49 . The majority of Tibetans are charged approximately 100 to 200 yuan per month. See id.

249. See id. at 57. Educational access can be restricted by the teacher's demand for gifts in exchange for favorable treatment. See id.

250. See id. Educational access is sometimes restricted by whom a child's parents know. See id.

251. See RACIAL DISCRIMINATION REPORT, supra note 238, at 10. "A primary barrier to academic success for Tibetan Children is the overwhelming use of Chinese as the teaching language in most schools in Tibet." Id. China resists teaching about the Tibetan history and culture. See id.

252. See ICLT, supra note 218 , at 59 . The Chinese want to indoctrinate rather than educate. See id. See also RACIAL DISCRIMINATION REPORT, supra note 238, at 10 . The education curricula for Tibetans is "closely monitored and controlled by the central government." Id.

253. RACIAL DISCRIMINATION REPORT, supra note 238, at 11.

254. ICLT, supra note 218, at 66.

255. See RACIAL DISCRIMINATION REPORT, supra note 238 , at 9.

256. See id. at 11. See also ICLT, supra note 218 , at 69 . Tibetan children are segregated from Chinese children; Tibetan children pay higher fees; Chinese children receive free food and supplies; and Tibetan children have to pay for these items. See id. Some schools offer better classrooms to Chinese children. See id.

257. See RACIAL DISCRIMINATION REPORT, supra note 238, at 12. See also CERD, supra note 133. Article 5(e)(i) provides, "The rights to work, to free choice of employment, to just and favourable [sic] conditions of work, to protection against unemployment, to equal pay for equal 
violation of the International Covenant on Economic, Social and Cultural rights, which provides to everyone the right to work and gain a living through work. $^{258}$ This discrimination is related to China's encouragement of Chinese settlement in Tibet. ${ }^{259}$ The Chinese are encouraged to settle and work in Tibet by being directly imported into Tibet, and they are offered incentives such as higher salaries, which are not offered to Tibetans. ${ }^{260}$ Employment discrimination against Tibetans is shown by the unemployment rates, which are on the rise, and the fact that it is difficult to obtain a job when most businesses are now owned by Chinese. ${ }^{261}$ China's failure to eliminate discrimination serves to perpetuate the political powerlessness of the Tibetan people. ${ }^{262}$ Due to this discrimination, Tibetans suffer economically because it is harder for them to "maintain their current employment, find new employment and start new businesses." 263

\section{E. Suppression of Religious Freedom}

The Chinese authorities restrict the freedom of religion in Tibet. ${ }^{264}$ This is in violation of the International Covenant on Civil and Political Rights. ${ }^{265}$ The Chinese authorities believe that Buddhism ${ }^{266}$ must be controlled in order

work, to just and favourable [sic] remuneration." Id.

258. See CESCR supra note 164 and accompanying text.

259. See RACIAL DisCRIMINATION REPORT, supra note 238, at 12 . See also PRoving, supra note 65, at 87. Annual wages for Chinese workers in Tibet are eighty-seven percent higher than in China. See id. Vacations for Chinese workers in Tibet are longer than those working in China. See id. Finally, "Chinese entrepreneurs receive special tax exemptions and loans at low interests [sic] rates in Tibet, whereas for Tibetans starting an enterprise in their own homeland, even obtaining a licence [sic] is difficult." Id.

260. See RACIAL DISCRIMINATION REPORT, supra note 238, at 12.

261. See id. at 13. One example of favoritism of Chinese over Tibetans is in the tour guide field. See id. The Chinese have laid down strict requirements, while recruiting more than one hundred Chinese settlers to become tour guides. See id. Some of the strict restrictions include the requirement of a middle school certificate and the condition that they pass a political examination. See id. The government also refused to renew permits for Tibetan tour guides who visited India without permission. See id. at 14.

262. See Radin, supra note 15 , at 697.

263. RACIAL DISCRIMINATION REPORT, supra note 238, at 14.

264. See ASIA WATCH REPORT, supra note 181, at 65.

265. See CCPR supra note 150 and accompanying text.

266. For a discussion of Tibetan Buddhism, see generally REPORT, supra note 91 . See also VAN WALT VAN PRAAG, supra note 8 , at 2 . Lamaism, which is practiced in Tibet, is a type of Buddhism that was brought to Tibet by the wives of King Songsten Gampo, Princess Bhrkuti of Nepal and Princess Wen-Cheng of the Tang Dynasty. See id. See also REPORT, supra note 91, at 110. The Dalai Lama is the most powerful figure in Tibetan Buddhism and the Panchen Lama is the second most powerful figure. See id. See also Senate Hearing, supra note 1, at 64 (prepared statement of Robert A. F. Thurman). The Buddhist society is an educational society. See id. See also People in Tibet at http://www.savetibetonline.com/peopleintibet.htm (last visited Sept. 6, 2001) [hereinafter SaveTibet]. Religion is important to Tibetans because "[m] any live for the next life, rather than for the present." Id. The elder continuously pray for the liberation-enlightenment by murmuring the mantric prayer. See id. 
to develop a sense of allegiance to the Chinese state. ${ }^{267}$ These checks are done through controlling the availability of propaganda and through "state-imposed limits on monastic ordination." ${ }^{268}$ Human rights require that people be allowed to practice their faith as they wish, without state imposition. ${ }^{269}$ The Tibetan's freedom to practice Buddhism is also hindered by the Chinese authorities' refusal to allow free expression or dissent on Tibet's political issues. ${ }^{270}$

\section{F. Torture and Political Imprisonment}

The region's security forces ${ }^{271}$ commonly use torture. ${ }^{272}$ This is in violation of the United Nations Convention Against Torture and Other Cruel, Inhuman or Degrading Treatment or Punishment, which requires a full and fair investigation of all allegations of torture. ${ }^{273}$

In 1988, China's security chief "announced 'merciless repression' of all forms of protest against Chinese rule in Tibet."274 The Chinese interrogate Tibetans by using torture, ${ }^{275}$ which is in violation of the CAT. ${ }^{276}$ Seventy percent of Tibetans imprisoned throughout Tibet die while in custody of the Chinese authorities. ${ }^{277}$ Thirty-three different techniques of torture have been described, with new methods continuously being developed. ${ }^{278}$

China imposes arbitrary arrest upon many Tibetans, ${ }^{279}$ which is in violation of the UDHR. ${ }^{280}$ Political imprisonment is the principal means by

267. See ASIA WATCH REPORT, supra note 181, at 65. See also REPORT, supra note 91 , at 111. The Chinese believe religion is the chief obstacle to controlling Tibet. See id.

268. ASIA WATCH REPORT, supra note 181, at 65.

269. See id. at 68.

270. See id. at 65. See REPORT, supra note 91, at 110 . Tibetans feel that China's control is an assault on their identity as a religious society because Tibetan's have a strong connection between religion and government. See id.

271. See ASIA WATCH REPORT, supra note 181, at 49.

272. For personal accounts of torture see generally ASIA WATCH REPORT, supra note 181.

273. See CAT, supra note 141.

274. PROVING, supra note 65, at 49. See also ASIA WATCH REPORT, supra note 181, at 30. Even after this "policy" was established, large numbers of Tibetans who had participated in demonstrations were released from prison because the authorities felt their repressive measures had been effective in eradicating dissent or the government began to realize the adverse impact of human rights violations were having on China's international image. See id.

275. See Proving, supra note 65, at 52.

276. See id.

277. See id. at 47.

278. See id. at 53 . These methods of torture include beatings with electric cattle-prods, rifle-butts, sticks, and iron bars. See id. at 52-53. Other methods include the use of electric shock, kicking, punching, mutilation, setting guard dogs on prisoners, and cigarette burns. See id.

279. See id. at 51.

280. Article 9 states, "No one shall be subjected to arbitrary arrest, detention or exile." UDHR, supra note 119. 
which China imposes its authority upon dissenting Tibetans. ${ }^{281}$ Chinese authorities impose sentences upon political prisoners, ${ }^{282}$ which are often out of proportion with the degree of the alleged crime. ${ }^{283}$ This practice violates the "internationally recognized right to freedom of political belief and to the peaceful expression of such beliefs." 284

Under Chinese rule, prisoners do not receive the right to be informed about the grounds of their arrest ${ }^{285}$ or their legal remedies. ${ }^{286}$ Many different activities can give rise to arrest and detention. ${ }^{287}$ The right that so many people enjoy, the right to be presumed innocent until proven guilty, does not exist under Chinese law. ${ }^{288}$

\section{SELF Determination}

\section{A. The right to self-determination}

The right to self-determination ${ }^{289}$ has traditionally been described as a "people's quest for greater autonomy and for a separate state."290 Under

281. See ASIA WATCH REPORT, supra note 181 , at 29 . Security raided a monastery at night and arrested a small group of monks who participated in protests. See id.

282. See Tibetan Centre for human RIGHTS DEMOCRaCy, PRISONERS of TiBet: PRofiles OF CURRENT POLITICAL. Prisoners 1 (2000). A political prisoner is one who is held in prison for exercising his or her basic human right of expression, which usually is in the form of small, peaceful demonstrations or the distribution of printed materials. See id.

283. See Proving, supra note 65, at 53.

284. ASIA WATCH REPORT, supra note 181, at 29.

285. See Proving, supra note 65, at 53. Being told the grounds for arrest is the exception in China rather than the law. See id.

286. See id. at 51. Because arrest warrants are rarely issued, the prisoner is not legally arrested, so the authorities do not inform the prisoner's family about the initial detention. See id. at 52.

287. See id. at 51. Some examples of activities that have given rise to arrest include: Tibetans have been arrested for speaking with foreigners, or singing patriotic songs, or putting up wall posters, or possessing copies of an autobiography of the Dalai Lama or some video or audio cassette, or for preparing a list of casualties during Chinese crackdowns on demonstrations, or for 'plotting' and advising friends to wear the traditional Tibetan costume on Chinese national day ... [or] for no apparent reasons.

Id. at $51-52$

288. See id. at 53.

289. See generally Gerry J. Simpson, The Diffusion of Sovereignty: Self-Determination in the Post-Colonial Age, 32 STAN. J. INT'L L. 255 (1996). One rationale for this right is the need to protect the collective human and democratic rights of minorities and unrepresented peoples. See id. at 258.

290. Ediberto Roman, Substantive Self-Determination: Democracy, Communicative Power and Inter/National Labor Rights Reconstructing Self-Determination: The Role of Critical Theory in the Positivist International Law Paradigm, 53 U. MIAMI L. REV. 943, 944 (1999). This right "is grounded on human rights precepts that recognize that all peoples are "equally entitled to be in control of their own destinies." Id. at 945. 
international law, "[a]ll peoples have the right of self-determination."291 The right of peoples ${ }^{292}$ to self-determination ${ }^{293}$ is recognized under international law as "the right freely to determine, without external interference, their political status and pursue their economic, social and cultural development."294

The concept of self-determination ${ }^{295}$ originated throughout Europe and the United States in the Eighteenth century. ${ }^{296}$ "Under modern international law, the right of peoples to self-determination does not presume a right to secession, but rather aims at the establishment of internal conditions for the enjoyment of all human rights."297 This right has limitations in place so as to maintain stability and protect the rights of people and societal interests. ${ }^{298}$

291. Article 1(1) of the CCPR provides, "By virtue of [the] right [to self-determination] they freely determine their political status and freely pursue their economic, social and cultural development." CCPR, supra note 150. See also, MORTIMER SELLERS (ED.), THE NEW WORLD ORDER: SOVEREIGNTY, HUMAN RIGHTS, AND THE SELF-DETERMINATION OFPEOPLES 10 (1996). This right extends to those who suffer from oppression, domination and exploitation by other governing bodies. See id. See Simpson, supra note 289, at 258. This right has been invoked more often than any other human right and enjoys greater recognition. See id.

292. See Radin, supra note 15 , at 711 . "A people is broadly defined as a group with a distinct culture, a territorial claim, and self-identification." Id. See also Julie M. Sforza, The Timor Gap Dispute: The Validity of the Timor Gap Treaty, Self-Determination, and Decolonization, 22 SUFFolK TRANSNAT'L L. ReV. 481, 498 (1999). "The United Nations Economic and Social Coop-eration Organization defines 'peoples' as individuals who relate to one another not just on the level of individual association, but as a separate and identifiable group within a specific territory." Id.

293. For a general discussion on the right to self-determination see generally THOMAS D. MusGraVe, SELF-DETERMINATION AND NATIONAL MINORITIES (1997).

294. INTERNATIONAL COMMITTEE OFLAWYERS FOR TIBET AND UNREPRESENTED NATIONS and Peoples Organization, THE Case Concerning Tibet: Tibet's Sovereignty and THE TIBETAN PEOPLE'S Right to SElf-Determination 3 (Dec. 1998) [hereinafter THE CaSE CONCERNING TIBET]. See also Radin supra note 15, at 705. "The right to self-determination expressly incorporates cultural integrity by guaranteeing the right of peoples to pursue economic, social, and cultural development." Id. See also MUSGRAVE, supra note 293, at 1. Self-deter-mination occurs when the political status of a people is freely determined by the people. See id.

295. See REPORT, supra note 91, at 21. The collective Right of self-determination of people has two aspects: on the one hand, is its original version prohibiting colonialism or foreign rule, and, on the other is its new incarnation which prohibits oppression and arbitrary exercise of any authority, implying thereby respect for human rights and dignity, responsive government, or democracy.

Id.

296. See MUSGRAVE, supra note 293, at 2 . Self-determination has evolved from a political concept prior to World War II to a legal right. See id. at 63. This change is due to the association of the right with decolonization. See id. at 97 . See also Sforza, supra note 292, at 493. "The principle originated following World War I with the development of the League of Nations Mandate System, which sought to further a goal of leading territory under the control of colonial powers towards self-determination." Id. at 492-493.

297. Radin, supra note 15 , at 696.

298. See SELERS, supra note 291 , at 10. 
These limitations $\mathrm{s}^{299}$ include territorial integrity ${ }^{300}$ and the doctrine of "uti possidetis juris." ${ }^{301}$ Self-determination, a concept recognized as a way in which colonies might gain their independence soon became identified with decolonization. ${ }^{302}$ However, alternative models, such as national self-determination, ${ }^{303}$ democratic self-determination, ${ }^{304}$ devolutionary self-determination, ${ }^{305}$ and secession have re-emerged to challenge the colonial model. ${ }^{306}$

The Tibetans are a "people" 307 because they have a distinct culture in their language, religion and political structures. ${ }^{308}$ Additionally, the Tibetans have held a territorial claim to the area since the Tibetan Empire, and they identify themselves as Tibetans, not as Chinese. ${ }^{309}$ According to the United Nations definition of "people", the Tibetans qualify as a "people" because they occupy an area of land that is geographically separate from China. ${ }^{310}$ The notion that Tibetans may achieve self-determination ${ }^{311}$ raises an issue of

299. See id. at 18. Another limitation on the right to self-determination is in the interpretation of the right. See id. When interpreting this right, one must take into account all other principles of the Charter of the United Nations such as the "prohibition of the use of force; prohibition of intervention in the domestic jurisdiction of a state; duty to settle disputes by peaceful means; duty to cooperate with other states; sovereign equality of states; and fulfillment by states of obligations in good faith." Id.

300. See id. at 19. Territorial integrity is the idea that one must not take action to dismember the territory of an independent state. See id.

301. See Sforza, supra note 292, at 515. "Uti possidetis, often mistaken and confused with the principle of territorial integrity, requires maintenance of existing colonial boundaries upon independence of a non-self-governing territory from its administering power." Id. "The principle of uti posseditis works to maintain the territorial status quo at the time of a colony's independence, requiring respect by other nations for the frontiers established in prior international agreements and internal administrative divisions." Id. at 500.

302. See Simpson, supra note 289 , at 265 . This "transformed decolonization into the only legitimate goal of self-determination. ..." Id.

303. See id. at 276. This type of self-determination can be seen as powerful in emotional appeal and lacking in intellectual persuasiveness or as a form of self-expression, which is vital to realizing human interests. See id.

304. See id. at 278 . This critique assumes that self-determination presents itself in undemocratic form. See id.

305. See id. at 280 . This type of self-determination includes arrangements that distribute power to local groups. See id.

306. See id. at 274-275.

307. See MUSGRAVE, supra note 293 , at 102 . Ethnic groups claim that they are entitled to the right of self-determination, which grew out of the occurrence of nationalism. See id. Modern technology has allowed ethnic groups to have a heightened consciousness of their identity, along with economic interdependence, which corresponds with ethnic divisions. See id.

308. See Radin, supra note 15 , at 711.

309. See id.

310. See Sforza, supra note 292 , at 499.

311. See id. at 492 . "It is for the people to determine the destiny of the territory and not the territory the destiny of the people." Id. 
secession, which "conflicts with the principle of the territorial integrity of states." 312

United Nations provisions provide, ${ }^{313}$ "[M]ember states must act in a manner that does not impede the right to self-determination of non-selfgoverning territories either by direct suppression of the right, non-action, or support of parties whose acts in this regard contravene U.N. purposes." ${ }^{314}$ The Charter of the United Nations ${ }^{315}$ requires the well-being and interests of the peoples of non-self governing territories to be of the utmost importance to the governing territory. ${ }^{316}$ In the Case Concerning East Timor, the International Court of Justice (I.C.J.) stated that entitlement to the right of selfdetermination "is not extinguished due to forcible intervention by a third party, by the passage of time, or by failed attempts at decolonization." 317 The I.C.J. in Western Sahara presented three alternatives for non-self-governing territories: "emergence as a sovereign independent State; free association with an independent State; or integration with an independent State."318 "[M]any claims for self-determination have arisen because an unjust, state-based, international legal order has failed to respond to the legitimate aspirations of peoples." 319

312. MUSGRAVE, supra note 293, at 104. "Most states have been very reluctant to recognize secession as a part of self-determination, and therefore deny that ethnic groups have any right to self-determination." Id.

313. Paragraph 2 of Article 1 provides, "The Purposes of the United Nations are . . To develop friendly relations among nations based on respect for the principle of equal rights and self-determination of peoples, and to take other appropriate measures to strengthen universal peace." U.N. CHARTER, supra note 115.

314. Sforza, supra note 292, at 501.

315. Article 73 provides:

Members of the United Nations which have or assume responsibilities for the administration of territories whose people have not yet attained a full measure of self-government recognize the principle that the interests of the inhabitants of these territories are paramount, and accept as a sacred trust the obligation to promote to the utmost, within the system of international peace and security established by the present Charter, the well-being of the inhabitants of these territories, and, to this end:

1. to ensure, with due respect for the culture of the peoples concerned, their political, economic, social, and educational advancement, their just treatment, and their protection against abuses;

2. to develop self-government, to take due account of the political aspirations of the peoples, and to assist them in the progressive development of their free political institutions according to the particular circumstances of each territory and its peoples and their varying stages of advancement. ...

U.N. CHARTER, supra note 115.

316. See id. See also MUSGRAVE, supra note 293, at 124. Self-determination includes the process of decolonization, which occurs by granting self-government to non-self-governing territories and usually creates an independent state. See id.

317. Sforza, supra note 292, at 510.

318. Id. at 495 .

319. SELLER, supra note 291 , at 10-11. 
Human rights are essential in developing the right to selfdetermination, ${ }^{320}$ as shown by the fact that the right is included in the International Covenant on Economic, Social and Cultural Rights ${ }^{321}$ and the International Covenant on Civil and Political Rights. ${ }^{322}$ Therefore, the legal rules applicable to international human rights law are the appropriate legal framework for the right to self-determination. ${ }^{323}$ Self-determination has been criticized because of the inherent tensions between the majority who rules the land and the minority who is separated from the land. ${ }^{324}$

The Dalai Lama proposed a plan that advocated peace but not necessarily complete independence from Tibet. ${ }^{325}$ This "five point peace plan" is known as the Strasbourg Proposal. ${ }^{326}$

\section{B. Internal Right to Self-Determination}

An internal right to human rights protection and an external right to freedom from domination are incorporated into the right to selfdetermination. ${ }^{327}$ The internal right to self-determination is the entitlement to human rights protection, which "entitles a people to participate effectively in the decision-making process which affects the political, economic, social, and cultural conditions under which it lives." ${ }^{328}$ The internal right to self-

320. See SELLER, supra note 291 , at 9 . This right has been declared a human right in many treaties. See $i d$.

321. See CESCR, supra note 164.

322. See CCPR, supra note 150 .

323. See SELLERS, supra note 291 , at 10 . The following general legal rules can be discerned within the international human rights framework:

(1) Human rights are interpreted in the context of current standards; (2) Any limitations on the exercise of human rights are limitations to protect other rights or limitations to protect the general interests of society; (3) The limitations on human rights are considered narrowly, with consideration given to the circumstances of the relevant society; and (4) A victim of a violation of human Id. at 14.

rights must bring the claim.

324. See Guyora Binder, The Kaplan Lecture on Human Rights: The Case for SelfDetermination, 29 STAN. J. INT'L L. 223, 225 (1993). This right has fused the value of popular sovereignty with the value of national resentment of occupation, which are two incompatible values. See id. at 226.

325. See REPORT, supra note 91 , at 109.

326. See id. The five points of this plan are as follows:

[T]ransformation of Tibet into a zone of peace, an end to China's population transfer, respect for the fundamental human rights and democratic freedoms of the Tibetans, protection of Tibet's environment (including the cessation of China using Tibet for nuclear purposes), and earnest negotiations regarding the future of Tibet and the relation of its people with the Chinese.

Id.

327. See Radin, supra note 15 , at 706.

328. Eric Kolodner, The Future of the Right to Self-Determination, 10 CONN. J. INT'LL. 153, 159 (1994). 
determination is threatened when there is a high level of deprivation. ${ }^{329}$ Elimination of racial discrimination is the key to promoting internal selfdetermination. ${ }^{330}$

The Tibetans are entitled to the internal right to self-determination because the Chinese are neither respecting the Tibetan's human rights nor upholding their promise to give Tibet a certain degree of autonomy. ${ }^{331}$

\section{External Right to Self-Determination}

The external right to self-determination is the freedom from domination, which "entitles a people to decide its international identity and 'to be free from foreign interference which affects the international status of that state." 332 The exercise of external self-determination does not involve secession; ${ }^{333}$ however, situations may exist in which there is a legitimate claim to the external right of self-determination, ${ }^{334}$ so as to protect the interests and rights of the people. $^{335}$

When determining whether a group is entitled to the external right to self-determination, the international community must scrutinize the group by examining objective elements to determine whether the group shares a common background and heritage. ${ }^{336}$ Subjective elements must then be examined to determine whether the group perceives themselves as a people within the meaning of self-determination. ${ }^{337}$ Once the group's assertion to the

329. See id. at 163. Deprivation must be due to the government's policies that render a people incapable of exercising any level of control over their lives. See id. The Chinese prevent the Tibetans from exercising control over their lives by exploiting Tibet's natural resources for the benefit of China, by de-emphasizing the use of the Tibetan language, which is rendering the language obsolete, and minimizing the importance of Tibetan history and culture. See id. at 165 . China also places a limit on how many monks are able to enter monasteries. See id.

330. See id. at 163. Discrimination plays a major part in the context of self-determination. See id. This discrimination is played out through China's policies that prevent Tibetans from exercising control over their internal right of self-determination. See id. at 165.

331. See REPORT, supra note 91, at 57.

332. Kolodner, supra note 328 , at 159 . Historically, this has been the focus of the international community. See id.

333. See id. at 160 . Rather than seceding from the territory, a people can become loosely federated with another State. See id. A people can take care of domestic affairs while allowing another State to control foreign affairs, or it can merge entirely with an existing State. See id.

334. See id. The Tibetan people being under Chinese control is an example of a situation in which there is a legitimate claim to the external right to self-determination because without the granting of this right, the interests of the Tibetans cannot be protected. See id.

335. See id. at 160.

336. See id. at 161 .

337. See id. The group as a people must share a sense of values and a common goal for the future of the community. See id. 
right to self-determination satisfies the two-prong test, it must then be scrutinized according to additional criteria. ${ }^{338}$

\section{CONCLUSION}

"A peaceful resolution of the Tibetan struggle will send a message to the world community that international disputes can be resolved peacefully through the rule of law." ${ }^{339}$ The Chinese need to take the Tibetan's claims to self-determination seriously because China has caused the Tibetans to live with numerous human rights violations, such as torture, discrimination, arbitrary detention, and coerced birth control.

Due to China's occupation and discriminatory treatment of Tibetans, there is a high level of human rights deprivation, and the Tibetans are unable to practice the culture in which they believe. The best remedy for the Tibetan people would be for China to recognize Tibet's right to self-determination and allow them to secede from China. This is an egregious case in which Tibet should be able to break free from China's rule and become independent in order to protect the Tibetans' interests in their own lives. By exercising this right, the Tibetans will live in a more peaceful world, and the number of human rights violations that are occurring in Chinese-occupied Tibet will decrease.

Regina M. Clark*

338. See id. This additional criteria includes the degree to which the group can form a working political entity, the consequences on the non-group members of granting the right, the effects upon the region, and the group's commitment to upholding international legal principles. See id.

339. International Committee of Lawyers for Tibet at http://www.tibeticlt.org/index.html (last visited Sept. 6, 2001).

* J.D. Candidate, 2002, Indiana University School of Law - Indianapolis; B.S., 1999, Business Management, Indiana University. Thank you to my family and friends for all of their love and support. To my mother and father, thank you for being a wonderful source of encouragement in my life. To my francé, Brian, thank you for believing in me and for your endless love and support in helping me pursue my dreams. To my friend, Katherine, thank you for sharing your knowledge and making me aware of all the injustice in the world. 